\title{
Evaluation of elderly care dynamics in an emergency care unit
}

\author{
Avaliação da dinâmica do cuidado ao idoso em unidade de pronto atendimento \\ Evaluación de la dinámica del cuidado al anciano en unidad de pronta atención
}

\section{Leidyani Karina Rissardo' \\ ORCID: 0000-0001-9498-0959}

Luciane Prado Kantorski"

ORCID: 0000-0001-9726-3162

Lígia Carreira'

ORCID: 0000-0003-3891-4222

UUniversidade Estadual de Maringá. Maringá, Paraná, Brazil. "Universidade Federal de Pelotas. Pelotas, Rio Grande do Sul, Brazil.

How to cite this article: Rissardo LK, Kantorski LP, Carreira L. Evaluation of elderly care dynamics in an emergency care unit. Rev Bras Enferm. 2019;0(Suppl 2):161-8. doi: http://dx.doi.org/10.1590/0034-7167-2018-0401

Corresponding Author: Leidyani Karina Rissardo E-mail: ka_rissardo@hotmail.com

Submission: 06-05-2018

Approval: 08-09-2018

\section{ABSTRACT}

Objective: understand elderly care dynamics of an emergency care unit. Method: this is a case study evaluation, using a qualitative approach and the theoretical-methodological reference of a fourth generation evaluation. Data collection was conducted between February and September 2017, through 460 hours of participant observation, interviews with 33 social actors among health professionals, elderly people and their relatives of an emergency care unit located in a municipality in the northwest of Paraná, as well as negotiation meetings with participants. Results: the evaluation showed the elderly care dynamics is mainly influenced by nursing actions that articulate care practices based on priority, frailty, autonomy, independence and family context of the elderly patients. Final considerations: an evaluation of how the emergency care unit operates helps improve elderly care in urgent and emergency services.

Descriptors: Health Care Evaluation; Medical Emergency Services; Health Care Quality; Elderly Health Services; Geriatric Nursing.

\section{RESUMO}

Objetivo: apreender a dinâmica assistencial do cuidado ao idoso inserido em um serviço de pronto atendimento. Método: pesquisa avaliativa com abordagem qualitativa, do tipo estudo de caso, apoiada no referencial teórico-metodológico da avaliação de quarta geração. A coleta de dados aconteceu entre fevereiro e setembro de 2017, por meio de 460 horas de observação participante, entrevistas com 33 atores sociais dentre profissionais de saúde, idosos e familiares de idosos de uma Unidade de Pronto Atendimento de um município do noroeste do Paraná, além de reuniões de negociação com os participantes. Resultados: a avaliação permitiu evidenciar que a dinâmica assistencial tem implicação, principalmente, das ações da enfermagem que necessitam articular práticas de cuidado que considerem a prioridade, a fragilidade, a autonomia, a independência e o contexto familiar do idoso. Considerações finais: avaliar o funcionamento da unidade contribui para a melhoria do cuidado ao idoso nos serviços de urgência e emergência.

Descritores: Avaliação em Saúde; Serviços Médicos de Emergência; Qualidade da Assistência à Saúde; Serviços de Saúde para Idosos; Enfermagem Geriátrica.

\section{RESUMEN}

Objetivo: identificar la dinámica asistencial del cuidado al anciano en un servicio de pronta atención. Método: investigación evaluativa con abordaje cualitativo, de tipo estudio de caso, con base en el marco teórico-metodológico de la evaluación de cuarta generación. La recolección de datos ocurrió entre febrero y septiembre de 2017, por medio de 460 horas de observación participante, con entrevistas con 33 actores sociales entre profesionales de salud, ancianos y familiares de ancianos de una Unidad de Pronta Atención de un municipio del noroeste de Paraná (Brasil), además de reuniones con los participantes. Resultados: la evaluación permitió identificar que la dinámica asistencial de las prácticas de enfermería necesita la articulación de prácticas de cuidado que consideren la prioridad, la fragilidad, la autonomía, la independencia y el contexto familiar del anciano. Consideraciones finales: evaluar el funcionamiento de la unidad contribuye a mejorar el cuidado al anciano en los servicios de urgencia y emergencia. Descriptores: Evaluación en Salud; Servicios Médicos de Urgencia; Calidad de la Atención de Salud; Servicios de Salud para Ancianos; Enfermería Geriátrica. 


\section{INTRODUCTION}

Population ageing has affected the demographic and epidemiological profile of society, creating demands that require responses from health policies and implying new forms of care, especially urgent and emergency services ${ }^{(1)}$.

International studies have reported that 12 to $29 \%$ of users of urgent and emergency units are elderly ${ }^{(2-3)}$, a percentage that corresponds to about $43 \%$ of the total number of visits at a national level ${ }^{(4)}$. Considering that old age involves a high number of chronic conditions and frequent aggravation of these conditions increases the demand for urgent and emergency services ${ }^{(5)}$, these health care units should provide care that fulfills the specific needs of the current demands of this population ${ }^{(2)}$.

The elderly people have specific needs resulting from clinical, functional, social and family characteristics that are peculiar to the ageing process ${ }^{(1)}$, reflected in longer hospitalization, high frequency of readmission, slower recovery, and even disability, which leads to increased treatment costs and differentiated care for these patients ${ }^{(6)}$. Therefore, the functionality of emergency services must consider articulations that address the specific needs of this population ${ }^{(7)}$.

Changes and developments have been implemented in urgent and emergency services over the years. One of the most recent innovations was the creation of the 24-hour Emergency Care Units (UPA 24h), implemented in 2008 after urgent and emergency care restructuring, based on the National Emergency Care Policy ${ }^{(8)}$.

These units are non-hospital health facilities of intermediate complexity that act as an interface between the Basic Health Units (UBS)/Family Health Strategies (ESF) and the hospitals ${ }^{(8)}$. Considering the recent implementation and regulation process of these units in the country, scientific investigations about their health care dynamics are still scarce, so studies are required on the new care scenario(5).

Given such factors, combined with increasing number of ageing population and the importance of health care for the elderly people, the following study question was developed: how do health professionals, elderly patients and their relatives evaluate the elderly care dynamics of one UPA 24h? Evaluation studies, particularly with a participatory perspective, help fill this scientific gap about the subject and develop actions that promote improvements in the health conditions of this population group.

\section{OBJECTIVE}

Understand elderly care dynamics of an emergency care unit.

\section{METHOD}

\section{Ethical aspects}

This study was developed after approval by the Ethics Committee for Research with Human Beings of Universidade Estadual de Maringá. All participants signed an informed consent form in duplicate.

In order to ensure the anonymity of the social actors, excerpts of the interviews were identified by the sequence of interviewees, followed by letter $P$ (professional), $E$ (elderly patient) and $F$ (family member) and a brief characterization of profession and degree of relationship between the family member and the elderly patient.

\section{Theoretical and methodological reference}

This study used a fourth generation evaluation as theoreticalmethodological reference. It proposes a constructivist and responsive evaluation, based on a hermeneutic and dialectical approach. It is hermeneutic for its interpretive character, it is dialectical because it proposes a debate of opinions about the study theme, it is constructivist as it allows a (re)interpretation of the facts, and, lastly, it is responsive because it covers important aspects for the evaluation: the stakeholder's claims, concerns and issues $(\mathrm{CCl})$ for the evaluation process ${ }^{(9)}$.

\section{Study design}

This is a case study evaluation, using a qualitative approach and the theoretical-methodological reference of a fourth generation evaluation. A case study was used in a fourth generation evaluation because it helps describe the real context of the study theme and explore specific contexts, allowing the identification of the study reality and its correlation with theory and practice of the services and programs evaluated ${ }^{(9)}$.

\section{Procedures}

\section{Study site}

The study site was one UPA $24 \mathrm{~h}$ of a municipality in the northwest of Paraná, characterized as level II by the Ministry of Health. According to internal records, this unit receives, on average, 400 patients/day, and $22 \%$ of them are elderly patients.

\section{Data collection and organization}

Three groups were included in this study: one had 13 health professionals, one had 12 elderly patients, and one had eight relatives of the elderly patients, totaling 33 social actors. Inclusion criteria for health professionals were: have worked in the service for more than six months and provide care directly to elderly patients. Inclusion criteria for the elderly patients were: patients who used the UPA $24 \mathrm{~h}$ services at least once in the last four months, and who had preserved cognitive status, as evaluated through the Mini Mental State Examination (MMSE). The elderly relatives included in this study were those listed as the main caregiver of the elderly patient who accompanied him/her during a visit to UPA $24 \mathrm{~h}$.

The fourth generation evaluation process was conducted from February to September 2017, and the practical procedures observed the following steps: Field contact (proposal introduced to UPA management), Organization of the evaluation (participant observation), Identification of stakeholder groups (health professionals, elderly patients and relatives), Development of joint constructions (application of the dialectical hermeneutic circle), Expansion of joint constructions (insertion of new information in 
the circle), Negotiation agenda (organization of constructions of each group and agreement about the negotiation day, site and time), Negotiation itself (meeting with each stakeholder group for data validation and consensus); and, finally, Construction of final results of the evaluation process (definition of thematic axes according to the excerpts/testimonies qualified after negotiation) ${ }^{(9)}$.

The field contact meeting was held in February 2017. Then, in March, the participant observation began, totaling 460 hours in the field. The observation took place in the three work shifts and, initially, an overview of all the attendances, regardless of the age of the user ( 15 days with 120 hours). At the moment, he observed the institution's infrastructure, attendance flow chart and unit management plan

The field contact meeting was held in February 2017. Then, in March, participant observation started, totaling 460 hours of field work. Participant observation was performed in all three work shifts and, initially, a general view of the service was obtained, regardless of the patient age ( 15 days, 120 hours of observation), observing the site infrastructure, service flow diagram and management plan of the health care unit.

After this first step, care service was observed only for the elderly patients and their relatives, and it was divided by care category offered in UPA 24h, as follows: reception according to risk classification (seven days, 36 hours of observation), emergency care involving medication room, medical consult, laboratory and imaging exam room (13 days, 104 hours of observation), observation room (15 days, 120 hours of observation), and emergency room (nine days, 80 hours of observation). Observations ended, in each category, with event repetition and an understanding of the service dynamics and greater connection with the individuals, since the objective of this step was not to analyze the service, but understand its reality ${ }^{(9)}$. These observations were recorded in a field log, together with data such as address, telephone, and day of care of the elderly patients and family members who visited UPA $24 \mathrm{~h}$ during the observation period.

The study had an active participation of individuals involved in care activities conducted at the study site aiming to acquire an understanding of care dynamics in the service. The interviews were conducted from June to August 2017. This step started with the construction of a dialectical hermeneutic circle (DHC) for the stakeholders, first for health professionals, then for elderly patients, and finally for their relatives.

The first interview, of total three DHCs, was conducted with Respondent 1 (R1), when he was asked to answer the following questions: Tell me how elderly care is provided in UPA $24 \mathrm{~h}$ and tell me about the challenges experienced in this process. At the end of this interview, he was asked to choose another respondent, named $\mathrm{R} 2$, to talk about new formulations for elderly care in the service. However, before the interview with R2, the themes, concepts, values, concerns and issues proposed by $\mathrm{R} 1$ were analyzed by listening to the interview audio and reading its transcription, and relevant points were extract to enable Construction 1 (C1), which acted as a source of information to proceed to the interview with $\mathrm{R} 2$. This way, the interview with $\mathrm{R} 2$ enabled a new construction, named C2, which, in turn, guided the interview with R3, and so on. This data collection process was conducted for the three groups of stakeholders.
The selection of R1 was based on participant observation, and the others were selected sequentially as described above. The elderly and their relatives were interviewed at home and/or workplace visits scheduled in advance. Health professionals were interviewed in UPA 24h, in a reserved environment.

With the completion of a DHC for each group, which occurred with information redundancy, data were organized for the moment of negotiation with each group. The negotiation process started with a presentation of collected information, so that all participants could have access to the whole material and validate the information.

This moment was previously scheduled and had the participation of most interviewees. The negotiation with health professionals had lasted 4 hours and took place in the facilities of the health care unit. With the elderly patients, the negotiation lasted three and a half hours and with the relatives, three hours, and these two other negotiation processes were conducted in the community center of the neighborhood where UPA $24 \mathrm{~h}$ is located. Printed material was produced, containing a synthesis of data from the interviews with each specific group, and distributed to group members. An explanation was provided for the results from interviews through an oral presentation and use of audiovisual resources, aiming to promote discussion, validation and negotiation for the information obtained from interviews.

\section{Data analysis}

Data analysis was conducted together with the interviews using the constant comparative method. At the end of each interview, data were fully transcribed and the analysis was performed by identifying units of meaning and constructions of each respondent, aiming to present the content of the first interviews in the next interviews, producing new formulations of the issues highlighted in the statements. After concluding the DHCs, the units of meaning were grouped into thematic axes that were presented and discussed at the moment of negotiation ${ }^{(9)}$.

\section{RESULTS}

The units of meaning related to elderly care dynamics in UPA $24 \mathrm{~h}$, produced from interviews with three groups of stakeholders, are presented in the thematic category of Daily life and health: elderly care dynamics in an emergency care unit, which has the following subcategories described below.

\section{DAILY LIFE AND HEALTH: ELDERLY CARE DYNAMICS IN AN EMERGENCY CARE UNIT}

Among the activities conducted in UPA 24h, health professionals used in care dynamics the services available in the unit for both elderly patients and general population. These services refer to risk classification, medical consultation, intensive care in the emergency room, administration of medication, hospitalization (bath, basic care), and laboratory and imaging tests. Figure 1 shows the flow of these activities:

The organizational flow was discussed by the groups, with the identification of relevant aspects required for the provision of elderly care in UPA $24 \mathrm{~h}$. 


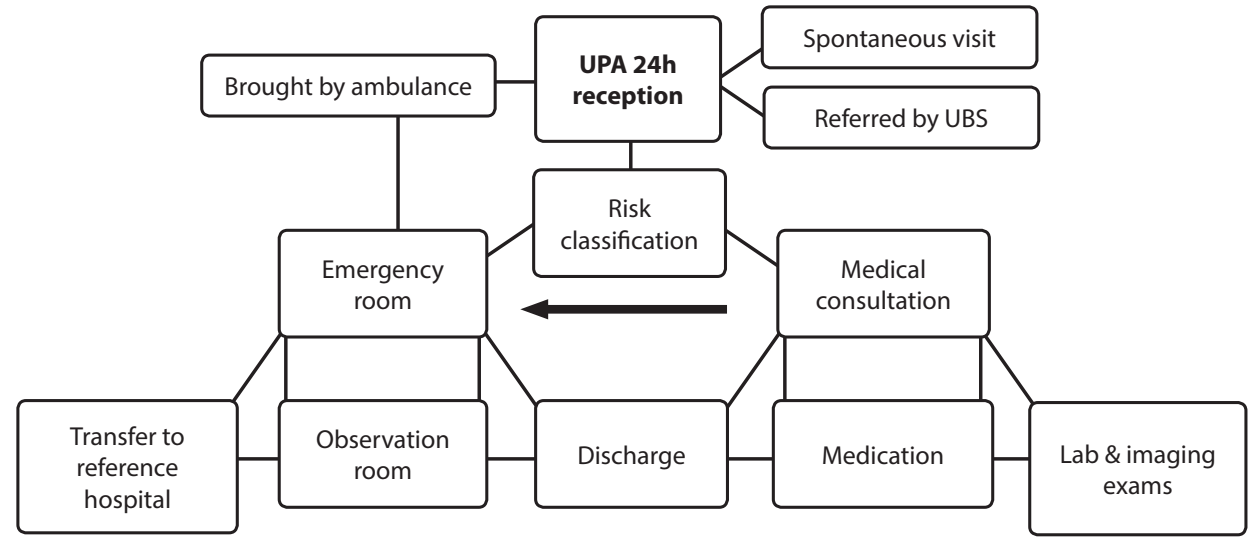

Figure 1 - Organization of elderly care in UPA 24h, Maringá, Paraná, Brazil, 2017
(R6-F-Public servant-Daughter of an elderly patient)

When I was there at UPA, there was a patient in a wheelchair who waited for one hour for an $x$-ray, I was touched. I guess they should have priority. (R3F-Kitchen assistant-Stepdaughter of an elderly patient)

Although the priority criteria for health care are set based on the patient severity, considering the patient's hemodynamic status and life-threatening situations, the elderly population should have priority in relation to other

\section{Frailty and priorities of elderly patients and their relation- ship with care practice in an emergency care unit}

When an elderly patient arrives at the UPA 24h, the reception fills a service form and transfers it, in order of arrival, to the area of risk classification (ACCR). The nurse in charge of the ACCR classifies the patient according to the severity level, configuring the practice of equity in urgent and emergency service.

The severity level, with its respective risk classification, determines the medical consultation place for the elderly patient. If the risk classification is blue or green, patients return to the reception. However, if it is yellow or orange, patients are accommodated in a corridor next to the medical rooms. For health professionals, this practice for frail elderly patients should be reformulated:

At risk classification, I think elderly patients should receive care according to the severity, and they also should have priority, as they have difficulty walking, and they go to risk classification, then back to reception if the risk is green and blue, and then again for medical consultation. And the elderly patients often have limited hearing acuity, they can't hear the doctor calling their names. The organization of our service should be rethought. (R10-P-Nurse)

In UPA, yellow and orange patients are taken inside, while blue and green patients wait outside [...]. Elderly patients are many times in a wheelchair, with a tube or gastrostomy, but sitting, so if a patient like this is classified as green, he has to wait outside, but I think he could wait inside. (R5- P-Physician)

Elderly patients have limitations due to senility and senescence, which differs them from other populations. Their health may be more vulnerable and their limitations increase progressively. Then, elderly frailty should be evaluated in the care unit context, taking such needs into account. This issue was a consensus among family members, who evaluated that the elderly frailty syndrome has to be considered when ACCR sets care priorities and in the whole care process in UPA 24h:

Elderly patients don't have priority just because they are elderly. My father had risk classification and returned to the reception with fever, $37.8^{\circ} \mathrm{C}$. Less than 10 minutes later, I asked someone to measure his thermometer, it was already 38.2, it increased. The nurses didn't consider that he is more sensitive than regular people. patients presenting the same severity, that is, the legal priorities are according to the risk classification color, observing the care process. The elderly patients and health professionals analyzed this issue as an aspect to be improved:

The elderly patients never have priority here at UPA, it's always in order of classification, in order of arrival, we don't give this priority to elderly patients [...] I've been told that I always have to take the first form, regardless of age, due to the time stamped on the form. (R5-P-Physician)

I don't go first because I'm old, some people are even worse than me. But some people are better and go before. I don't know the criteria they use, I don't know about this color system they are talking about. Perhaps that I might have been classified as black [laughs] maybe I'm kicking the bucket. (R6-E-Retired elderly patient)

The rights of the elderly people must be considered in the organization of health care services. At the negotiation with health professionals, they had an intense discussion about 'priority of elderly patients,' where challenges were identified, such as the overloaded staff in UPA 24h:

At risk classification we don't prioritize them either, because you could prioritize them in the classified color or even before the classification. But no, we don't do that, we end up choosing patients who complain more or to reduce the queue soon, because it's so crazy, full of people, the demand is great and we end up not giving this priority to elderly patients, as defined by law. (R2-P-Nurse)

The obstacle to recognizing the rights and needs of the elderly patients in care dynamics was also evaluated as a result of poor training of health professionals:

What bothers me most is the lack of training here at UPA. Lack of training, lack of study, and not everyone who works here is prepared to serve the elderly patients, provide care to the elderly [...]. I particularly don't know the rights of the elderly patients. We've never received training here in UPA about them, who are the most frequent patients we have here. (R6-P-Nurse technician)

I guess the municipal administration only hires and doesn't train them [health professionals], because UPA deals with life and there are so many old people there. [laughs] (R6-E-Retired elderly patient) 
Training discussions addressed the need for a greater incentive of nurses for permanent education in nursing, since this professional is a reference for the team.

Considering some limitations in the technical knowledge about the ageing process, elderly care dynamics in UPA 24h was evaluated as a hegemonic model of care based on mechanicism, presenting a gap in practices that include particularities of elderly patients, such as their autonomy and independence.

\section{Autonomy and independence of the elderly in the context of care in an emergency care unit}

The impact of the mechanistic model of elderly care in UPA $24 \mathrm{~h}$ was identified as practices that limit elderly self-care empowerment in this service, especially in terms of decisions about activities that could be made by the patient and/or his/ her family:

Bath is a complicated issue. Here at UPA, as it has a specific number of employees to adjust our routine, baths are performed in the morning, afternoon and at night [...] I think it's a great disrespect, at least the elderly patient could have the autonomy to choose the bath time, something that is so important for $\mathrm{him} / \mathrm{her}$, something that is so simple that we could solve and it doesn't happen. (R10-P-Nurse)

I said: "Nobody's going to give a bath to my husband! He likes to take a bath early in the morning, they said there were rules. So let me do give him a bath, it's not because he can't walk and talk that they're going to do what they want" [...] He answers with gesture, he understands what you say. (R1-F-Housewife-Wife of an elderly patient)

Although UPA 24h should be a temporary care unit, elderly patients remain hospitalized for several days. Delayed transfer requires health professionals to establish long-term care routines. In this context, families and health professionals emphasized that, in such routines, autonomy and independence of the elderly patients are limited in the nursing organization for basic care, such as bed bath, according to the statements above.

As stated by health professionals, discouragement of elderly autonomy and independence in care dynamics is influenced by the analogy that some members of the team attribute regarding old age and physical and cognitive disability:

We often underestimate the cognitive skills of elderly patients, their ability to provide information, and because of this problem, care is very limited [...] Health professionals have to be more aware of elderly care, change the stereotype we have of old grandpa, white hair, without an active sexual life and without autonomy. Meetings could be held sometimes to improve the quality of care. It's worth trying and proposing! (R10-P-Nurse)

The stereotype of elderly people with deficient autonomy and independence encourages attitudes and practices that disregard them as active individuals in the existential process and autonomous decision making process, affecting practices that involve other social actors, such as family members.

\section{Family members of elderly patients in professional care in an emergency care unit}

The groups of stakeholders evaluated the dynamics of hospitalization in UPA $24 \mathrm{~h}$ as an issue to be improved for the elderly patient appreciation and flexibility with the family, since law requires a full-time companion for patients aged 60 or over, regardless of their health vulnerability:

I believe that sometimes there's a lack of vision. Many professionals, when they receive an 80-year-old patient, for example, who is independent, who speaks well, who call tell right from wrong, even so that health professional requires a companion, which I find unnecessary; we have to appreciate independence of the elderly patient. (R12-P-Social worker)

The companion requirement for elderly patients is observed in all care dynamics of UPA $24 \mathrm{~h}$, except in the emergency room (ER). When an elderly patient needs intensive care in the ER, the family members are released and instructed to return at visiting period (9 am to 9:30 am). The static visiting period of the ER promoted reflections and suggestions to improve elderly care dynamics:

Visitors have access, but not accessibility. They may come to visit elderly patients, but at the time set by the institution and not the best time for them [...]. I had an experience and it opened my mind about this issue. An elderly person was in the emergency room after an AMI [acute myocardial infarction], and his granddaughter wanted to see him. I ended up letting the child in, other people fought with me, but he died the next day. (R10-P-Nurse)

On the first day of the month he stayed in the emergency room, he had two cardiac arrests, then he was taken to the municipal hospital early the next day. I didn't get to see him in UPA because of the time, if he had died I wouldn't have seen him again. (R3-FKitchen assistant-Stepdaughter of an elderly patient)

Istayed in the emergency room and I didn't receive any visit because my son has a job [...] and the company doesn't release him at this time. (R6-E-Retired elderly patient)

In the negotiation meetings with the three groups, they all agreed with the importance of the family in elderly care process in UPA 24h. According to them, the presence of a family member favors improvements in the quality of care; however, it requires flexibility regarding the presence of patient companion in the period of hospitalization and visiting period of the ER, avoiding frustration and suffering in that process. Then, they agreed on the family presence at the moment of the medical visit and the creation of a new visiting period out of business hours for the ER.

At the moment of negotiation of family members was scored, mainly, by those with dependent entities, the need of the family also be cared for without being judged by professionals of the UPA $24 \mathrm{~h}$. It should be noted that the home visits for the construction of the CHD of the relatives and the elderly contributed to the understanding of the lived reality, with singularities pertinent to sustain the results evaluated in the service in question 
In the negotiation meetings with the relatives, the family members, especially those with dependent elderly, highlighted the need for family care without judgments from UPA $24 \mathrm{~h}$ professionals. It should be noted that home visits for the CHD construction for elderly patients and their relatives helped understand their reality, with singularities that support the evaluation results of the service in question.

\section{DISCUSSION}

The groups of stakeholders discussed important parameters of the evaluation, which refer to the dimensions of care and the need to appreciate frailty, priority, autonomy, independence and the family of elderly patients in UPA $24 \mathrm{~h}$, as well as greater incentive for permanent education about peculiarities of the ageing process.

Although this service is not a specific health center for the elderly, the duties and rights of this population must be taken into account by all health care facilities, with a health team prepared to identify their needs. In terms of health care, nursing stands out not only for the number of professionals involved in urgent and emergency services, but also for the relevant role they play in care humanization and reception of individuals in emergency services ${ }^{(6,10)}$

This study confirms that the elderly care flow in UPA $24 \mathrm{~h}$ is based on the scientific role of nurses in ACCR, since the actions of this professional is directly related to the outcome of health care. Studies found in the literature recommend nurses as the main actor in the ACCR process ${ }^{(10-11)}$.

As frontline professionals, nurses should perform an overall assessment of elderly patients, taking into account their health singularities and needs, because Brazilian protocols of $\mathrm{ACCR}^{(12)}$ only focus biological aspects, not covering parameters of elderly frailty syndrome. The model used in the ACCR of the health care service analyzed in this study was adapted from the Manchester classification, where classification levels are determined according to the clinical condition of the patient ${ }^{(12)}$.

A Brazilian study highlights that risk classification through protocols is required for faster emergency care to elderly patients ${ }^{(6)}$. However, this classification may cause longer waiting times and more risks, which usually present complex social needs and clinical complaints about care. Because of atypical symptom presentation and the fact that elderly patients find it difficult to explain what they feel, many elderly people are evaluated as 'low risk' and submitted to long waiting periods, longer admissions and greater risks of readmission ${ }^{(6)}$. The adoption of instruments for elderly frailty screening may be crucial for identifying elderly frailty in a quick and concise manner and for the organization of care dynamics, contributing to the outcome of treatments provided to this population ${ }^{(2)}$.

In this sense, besides elderly frailty, another issue to be considered is elderly priority in urgent and emergency service. The ACCR protocol ${ }^{(12)}$ and the laws of elderly rights and duties in Brazil highlight aspects that involve priority care in the emergency service, with priority given to the elderly in relation to other patients with the same risk classification, except for red classification. Priority to elderly patients has been restructured, since people aged 80 and older have priority over people aged between 60 and 79 years ${ }^{(13)}$.

In the meantime, care dynamics structuring in UPA $24 \mathrm{~h}$ in terms of priority of elderly patients should be reviewed, since the rights of the elderly have to be respected. However, caution is needed because prioritizing age without considering the criteria of urgent and emergency services can contribute to inadequate classification of priorities in the emergency service ${ }^{(14)}$.

However, this evaluation observed limited professional preparation for the identification of elderly frailty and peculiarities of the aging process, which, combined with overloaded staff, provide mechanized elderly care in UPA 24h, without a heuristic vision that seeks to understand the real problems experienced by the elderly, only observing the stipulated logic of protocols and/or standards and routines. An international study agrees with this study and highlights urgent and emergency services that address themes in permanent education focused on population ageing, especially with training to nurses and subsequent knowledge transfer to the health team ${ }^{(15)}$.

At the negotiation with health professionals of UPA 24h, a discussion addressed permanent education and the influence of nurses in team training. One of the roles of nurses is to act as a team leader, placing them as a reference in building knowledge and practices for the health service ${ }^{(16)}$. In this sense, it is necessary to insist for nursing team to receive permanent training that makes nurses more critical and skillful in the process of elderly care, which includes the definition of 'elderly' and the identity granted to the elderly ${ }^{(17)}$.

This study found that, given the different responsibilities of nurses, the performance of this professional implies not only the organization of elderly care dynamics in UPA 24h, but also the quality of care provided, based on their commitment to permanent education for health professionals.

Care dynamics addressed in the interviews also involves long-term care in the service. Although it is a facility of urgent and emergency service, requiring fast care, the maintenance of practices that value elderly autonomy and independence can improve care outcome and the quality of life of these individuals ${ }^{(18)}$.

Standards and routines are extremely important for the organization of the service; however pre-established routines were seen as obstacles to stimulation of functional ability of elderly patients. It mainly results in losses to patients in bed with preserved autonomy, since they require professional care but do not have an active voice in this process ${ }^{(18)}$, for instance, in bath decision, as highlighted by some participants.

Care planning requires participation of involved subjects, based on individual care, stimulation to decision making and engagement of health professionals, elderly patients and their family members ${ }^{(19)}$. An identification of the degree of dependence in care planning would be essential for team sizing in urgent and emergency service to help reduce work overload ${ }^{(19)}$.

In addition, dialectics supports changes in actions and relations in UPA 24h, since popular participation in shared construction of care model is a movement that deserves appreciation. During the period of participant observation, the health council was identified in the service, which was unknown to most social actors. It has to be explored in order to allow negotiation among the actors involved in elderly care dynamics.

The complexities involved in the life of the elderly and their relatives have to be better understood. The fields of geriatrics and gerontology should take into account the elderly-family binomial ${ }^{(20-21)}$, since family members become spokespersons for the elderly when they have limitations. A partnership between the team and the family, even if it is not the ideal one, is essential for the therapeutic process 
of the elderly, also requiring an agreement to negotiate patient care and strategies to support the overload work of caregivers.

Therefore, actions for the families of elderly patients have to be inserted in UPA 24h. Strategies should be developed for family awareness, without blaming or assigning value judgments by health professionals, which stimulate care without pressure, promote shared responsibilities without verticalization and attention without judgment ${ }^{(21)}$.

\section{Study limitations}

The study limitations referred to its regionalization, as it was conducted in only one service, not allowing comparisons of findings, and the moment of negotiation, when although most of the stakeholders were present, the opinion of those who were absent could be different from consensus. However, home visits at DHC construction for the elderly patients and their relatives, in addition to the negotiation process, strengthened the evaluation reliability.

\section{Contributions to the area of nursing}

This study contributes to nursing as it shows a direct implication of nursing in elderly care dynamics in UPA $24 \mathrm{~h}$, allowing reflections on the practices and development of strategies that contribute to restructuring of health actions so that care will include beliefs and particularities of this age group in order to minimize the biomedical model.
The results also contribute to scientific emphasis on the importance of disciplines that address elderly health in nursing courses, with emphasis on care process based on the health needs of these individuals in urgent and emergency services.

\section{FINAL CONSIDERATIONS}

This study allowed an understanding of elderly care dynamics in UPA 24h. This evaluation showed that care in this service involves mechanical activities that limit the interpretation of inherent complexities of elderly patients.

The identification of lack of actions that address elderly frailty, priority, autonomy, independence and family context are relevant results that support changes in the behavior of health professionals who work in such health facilities. Of note, the concept of 'elderly' and the professional attitude are linked, requiring permanent education and reflections about the ageing process.

These results support the development of public policies for UPA $24 \mathrm{~h}$ expansion, with a focus on elderly patients. A fourth generation evaluation allowed discussions about elderly health care, improving and qualifying the issues that emerged from the evaluation process. Evaluation, as a formative assessment, enabled a privileged moment of mutual learning, contributing to the emancipatory process of the subjects involved. Further studies are suggested in other scenarios to add experiences and contribute to excellence in elderly care in emergency units.

\section{REFERENCES}

1. Veras R. Linha de cuidado para o idoso: detalhando o modelo. Rev Bras Geriatr Gerontol [Internet]. 2016 [cited 2017 May 18];19(6):887-905. Available from: http://www.scielo.br/pdf/rbgg/v19n6/pt_1809-9823-rbgg-19-06-00887.pdf

2. Brouns SHA, Joyce JW, Jonkers FS, Lambooij SL, Dieleman JP, Haak HR. Outcome of elderly emergency department patients hospitalised on weekends: a retrospective cohort study. BMC Emerg Med [Internet]. 2018 [cited 2016 Apr 5];18(9). Available from: https://bmcemergmed. biomedcentral.com/track/pdf/10.1186/s12873-018-0160-y

3. Gabayan GZ, Liang LJ, Doyle B, Huang DY, Sarkisian CA. Emergency Department Increased use of Observation Care for Elderly Medicare Patients. J Hosp Adm [Internet]. 2018 [cited 2016 May 18];7(3):9-16. Available from: http://www.sciedu.ca/journal/index.php/jha/article/ view/13070/8248

4. Acosta AM, Lima MADS. Frequent users of emergency services: associated factors and reasons for seeking care. Rev Latino-Am Enfermagem [Internet]. 2015 [cited 2018 Jan 5];23(2):337-44. Available from: http://www.scielo.br/pdf/rlae/v23n2/0104-1169-rlae-23-02-00337.pdf

5. Rêgo AS, Rissardo LK, Scolari GAS, Sanches RCN, Carreira L, Radovanonic CAT. Factors associated with the care of elderly persons with Primary Health Care sensitive conditions. Rev Bras Geriatr Gerontol [Internet]. 2017 [cited 2018 May 19];20(6):773-84. Available from: http:// www.scielo.br/pdf/rbgg/v20n6/1809-9823-rbgg-20-06-00773.pdf

6. Santos MT, Lima MADS, Zucatti PB. Elder-friendly emergency services in Brazil: necessary aspects for care. Rev Esc Enferm USP [Internet]. 2016 [cited 2018 May 19];50(4):594-601. Available from: https://www.lume.ufrgs.br/bitstream/handle/10183/149447/001003791. pdf?sequence $=1$

7. Burkett E, Martin-Khan MG, Scott J, Samanta M, Gray LC. Trends and predicted trends in presentations of older people to Australian emergency departaments: effects of demand growth, population aging and climate change. Aust Health Rev [Internet]. 2017 [cited 2018 May 9];41(3). 246-53. Available from: https://www.ncbi.nlm.nih.gov/pubmed/27466861

8. Conselho Nacional de Secretários de Saúde (BR). Rede de Atenção às Urgências e Emergências: Avaliação da Implantação e do Desempenho das Unidades de Pronto Atendimento (UPAs) [Internet]. Brasília: CONASS; 2015[cited 2018 May 9]. (CONASS Documenta, 28). Available from: http://www.conass.org.br/biblioteca/pdf/Conass_Documenta_28.pdf

9. Guba EG, Lincoln YS. Avaliação de quarta geração. Campinas: Editora Unicamp; 2011.

10. Duro CLM, Lima MADS, Weber LAF. Nurses' opinion risk classification in emergency services. Rev Min Enferm [Internet]. 2017 [cited 2018 Apr 5]21:e-1062. Available from: http://hdl.handle.net/10183/174045 
11. Hermida PMV, Nascimento ERP, Echevarría-Guanilo ME, Brüggemann OM, Malfussi LBH. User embracement with risk classification in an emergency care unit: an evaluative study. Rev Esc Enferm USP [Internet]. 2018 [cited 2018 Apr 29];52:e03318. Available from: http://www. scielo.br/pdf/reeusp/v52/en_0080-6234-reeusp-S1980-220X2017001303318.pdf

12. Ministério da Saúde (BR). Política Nacional de Humanização da Atenção e Gestão do SUS. Acolhimento e classificação de risco nos serviços de urgência. Brasília: Ministério da Saúde; 2009. Available from: http://bvsms.saude.gov.br/bvs/publicacoes/acolhimento_classificaao_ risco_servico_urgencia.pdf

13. Ministério da Saúde (BR). Lei no 13.466, de 12 de Julho de 2017. Altera os arts. 3 o, 15 e 71 da Lei no 10.741, de 1o de outubro de 2003 , que dispõe sobre o Estatuto do Idoso e dá outras providências. Diário Oficial da União [Internet]. 2017[cited 2019 May 15]:1. Available from: http://www.planalto.gov.br/ccivil_03/_ato2015-2018/2017/lei/113466.htm

14. Kajsa E, Katarina W, Sten L, Synneve ID. Screening for frailty among older emergency department visitors: Validation of the new FRESHscreening instrument. BMC Emerg Med [Internet]. 2016 [cited 2018 Jan 13];16:27. Available from: https://bmcemergmed.biomedcentral. com/track/pdf/10.1186/s12873-016-0087-0

15. Song $\mathrm{M}$, Jin $\mathrm{X}, \mathrm{Ko}$ HN, Tak SH. Chief complaints of elderly individuals on presentation to emergency department: a retrospective analysis of South Korean National Data 2014. Asian Nurs Res[Internet]. 2016 [cited 2018 May 30];10:312-7. Available from: https://www.asiannursingresearch.com/article/S1976-1317(16)30244-4/pdf

16. Amestoy SC, Trindade LL, Silva GTR, Santos BP, Reis VRSS, Ferreira VB. Leadership in nursing: from teaching to practice in a hospital environment. Esc Anna Nery [Internet]. 2017 [cited 2018 May 5];21(4):e20160276. Available from: http://www.scielo.br/pdf/ean/v21n4/ pt_1414-8145-ean-2177-9465-EAN-2016-0276.pdf

17. Sanguino GZ, Previato GF, Silva AF, Meireles VC, Góes HLF, Baldissera VDA. The nursing work in care of hospitalized elderly: limits and particularities. Rev Pesqui: Cuid Fundam [Internet]. 2018 [cited 2019 May 14];10(1):160-6. Available from: http://www.seer.unirio.br/index. php/cuidadofundamental/article/view/6015/pdf

18. Selman LC, Daveson BA, Smith M, Johnston B, Ryan K, Sean M, et al. How empowering is hospital care for older people with advanced disease? barriers and facilitators from a cross-national ethnography in England, Ireland and the USA. Age Ageing [Internet]. 2017 [cited 2018 May 29];46(2):300-9. Available from: https://www.ncbi.nlm.nih.gov/pmc/articles/PMC5860377/

19. Hwang U, Dresden SM, Rosenberg MS, Garrido MM, Loo G, Sze J, et al. Geriatric emergency department innovations: transitional care nurses and hospital use. J Am Geriatr Soc [Internet]. 2018 [cited 2018 May 16];66(3):459-66. Available from: https://onlinelibrary.wiley.com/doi/ epdf/10.1111/jgs.15235

20. Souza AS, Andrade CC, Reis JAP, Meira EC, Menezes MR, Gonçalves LHT. Service hospitalized elderly: perceptions of health professionals. Ciênc Cuid Saúde [Internet]. 2013 [cited 2018 May 29];12(2):274-81. Available from: http://www.revenf.bvs.br/pdf/ccs/v12n2/en_10.pdf

21. Hagedoorn El, Paans W, Jaarsma T, Keers JC, Van der Schans C, Luttik ML. Aspects of family caregiving as addressed in planned discussions between nurses, patients with chronic diseases and family caregivers: a qualitative content analysis. BMC Nurs [Internet]. 2017 [cited 2018 May 10];16(37). Available from: https://www.ncbi.nlm.nih.gov/pmc/articles/PMC5504762/pdf/12912_2017_Article_231.pdf 